\title{
REDUCTION OF WATER CONTAMINATION, GAS EMISSION AND PRODUCTION OF ENERGY FROM THE WASTE OF DHAKA CITY, BANGLADESH
}

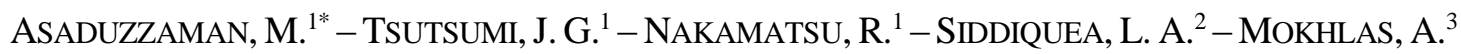 \\ ${ }^{1}$ Department of Civil Engineering, University of the Ryukyus, Okinawa 903-0129, Japan \\ ${ }^{2}$ Chorbashi Government School, Government Republic of Bangladesh, Tangail 1900, Bangladesh \\ ${ }^{3}$ Faculty of Agriculture, University of the Ryukyus, Okinawa 903-0213, Japan \\ *Corresponding author \\ e-mail: jamannoor@gmail.com; phone: +81-804-312-8793 \\ (Received $7^{\text {th }}$ Jun 2019; accepted $9^{\text {th }}$ Sep 2019)
}

\begin{abstract}
The current condition of waste management in Dhaka is a clear manifestation of poor sanitation in less developed nations. The city has been experiencing waste dumping on a daily basis. The aim of this research is to minimize waste, eliminate water contamination as well as greenhouse gas (GHG) emission by producing electricity from waste. An experiment was performed on a collection of wastewater samples and it was found that high level of water contamination is brought by extensive waste water contamination. The study found that wastewater from Dhaka city contained a diverse array of chemicals including toxic and non-toxic heavy metals, nitrates, phosphates, sodium $\left(\mathrm{Na}^{+}\right)$, potassium $\left(\mathrm{K}^{+}\right)$, sodium sulphate $\left(\mathrm{SO}_{4}{ }^{2-}\right)$, Calcium $\left(\mathrm{Ca}^{2+}\right)$, chloride $\left(\mathrm{Cl}^{-}\right)$and harmful polyaromatic hydrocarbons. A multivariate analysis was applied and the level of contamination was detected to exceed the World Health Organization (WHO) permissible limit in all areas. Software simulation was also used in data analysis. The study found that $90 \%$ waste collection rate and High tech solid waste incinerator plan could produce 262.125 MW electricity per day and potentially reduce 2.375 million tons GHG emission in total per year.
\end{abstract}

Keywords: water quality, green energy, water contamination, organic waste, and wastewater evacuation

\section{Introduction and literature}

Dhaka is the capital of Bangladesh. The city is surrounded by four main rivers along with their many small cannels. Apart from these water masses there are several inland lakes and lowland inside the city. The source of water for these water masses is rain and seasonal rivers. The city population is estimated to be around 19 million hence the city is considered as one of the most highly populated towns on Earth. Moreover, the city is known to produce tremendous amount of solid wastes on a daily basis. Rising waste volumes together with the increasing complexity of waste treatment have become not only a major and growing public health but also environmental concerns. Due to the population growth, changing lifestyle and spending sequence of individuals, the amount of waste production is ever growing. The eminence as well as the composition of wastes are varying radically. Water pollution is not only impacting water organisms alone but also damages the natural biodiversity.

From the map (Fig. 1) we can see rivers around Dhaka City. These water-bodies are highly polluted and have reached alarming levels of pollution that is both economic and health concerns to inhabitants, mainly to the less endowed in the city. Generally, consumption of water originated from several of sources such as rivers, lakes and ponds and ground water. These waters are contaminated with arsenic (As), a toxic metalloid. 
Arsenic exists in inorganic form $\left(\mathrm{As}^{3+}\right.$ and $\left.\mathrm{As}^{5+}\right)$ in aquatic system and poses a large public health threat when combined with methyl and dimethyl arsenic composites from natural systems including, anthropogenic as well as ecological sources (Chatterji, Arlosoroff and Guha, 2017; Cordonet al., 2018; Cui et al., 2018; Ijumulana et al., 2016). Comparative studies have shown that arsenic in water causes health risks such as generating non cancer effects, hypertension, cardiovascular diseases and diabetes (Tripathee et al., 2016; Khuhawar et al., 2019; Kumar et al., 2015; Song et al., 2016; Ijumulana et al., 2016). Inorganic arsenicals which fall in group I carcinogens create a high health risk which claims about 60-100 million people in India and Bangladesh after being found in drinking water as major contaminant from river, canal and lake (Huang et al., 2016; Antoniadis et al., 2017; Bettoschi et al., 2018). UNICEF has reported high awareness in Arsenic contamination in various parts in the country (Mehrotra et al., 2016; Ur Rehman et al., 2018).

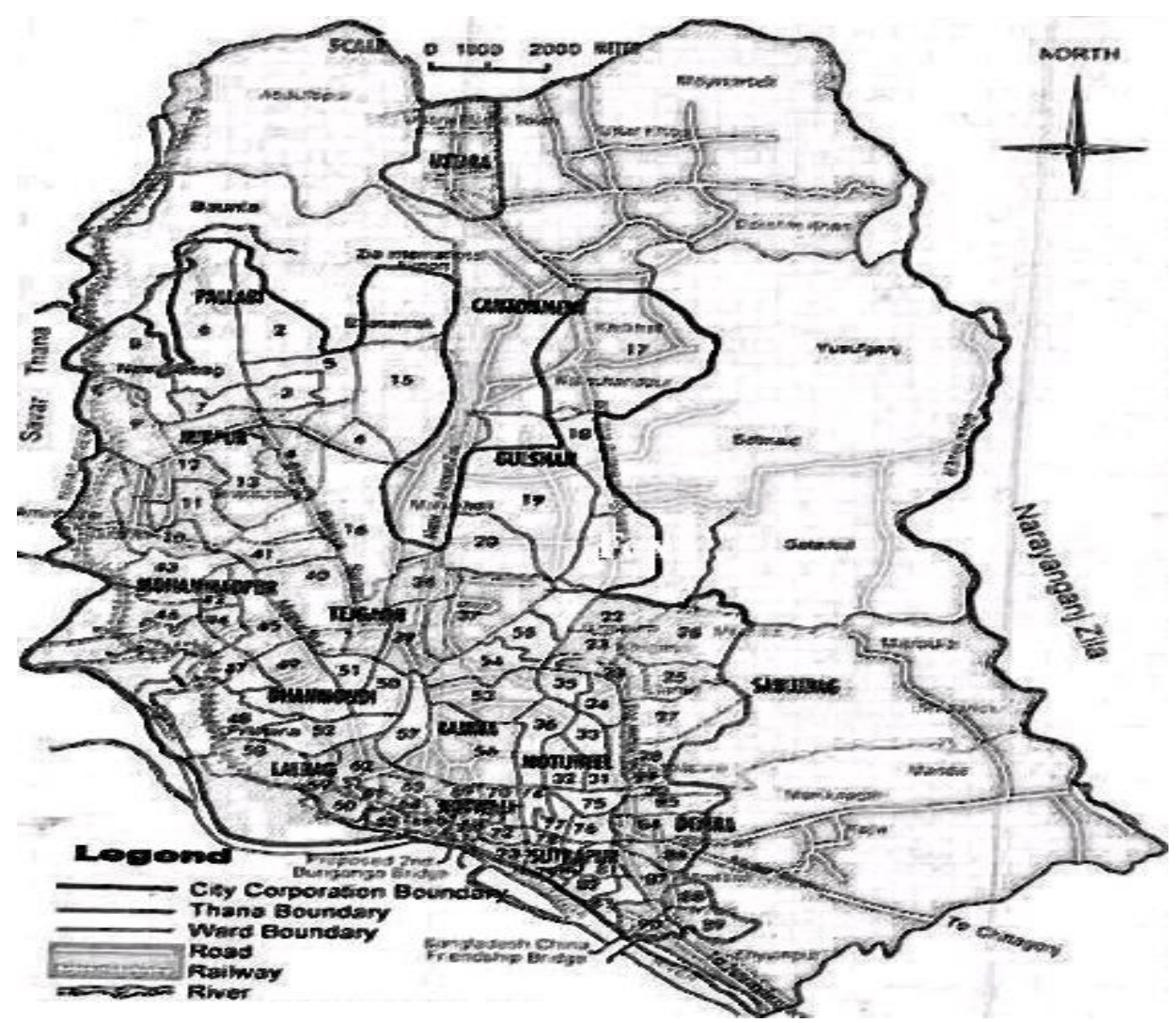

Figure 1. Dhaka City location map

This arsenic contamination happened due to household solid wastes, wastes from small industries and tannery effluents with multifarious features. The wastes are also linked with high level of organic pollutants mainly made up of chemicals as well as significant amounts of inorganic components which are toxic together which cause inhibitory effects on biological system (Ouyang et al., 2018 and Mohammadi et al., 2015). The water sources are polluted with more than 138 different pollutants. In addition, inhabitants are also throwing wastes directly and indirectly into the rivers. The biggest sources are Hazaribagh tannery wastes; water containing COD and the toxic stench wafting throughout the whole area is almost suffocating. Based on the current 
statistics lack of waste management in the city is turning out to be the main cause of water pollution. During the rainy season wastes and wastewater production is $100 \%$ higher than in the dry season.

The main supply of water in the city is $(83 \%)$ ground water and surface water $(17 \%)$. The peripheral rivers have undergone major pollution due to indiscriminate discharge of domestic and industrial wastes (Figs. 2-5). As a result, surface and ground waters are highly contaminated by different types of chemicals and microbes. Some other identified contaminants are residual chlorine, coliform and faecal coliform. According to Dhaka Water Supply and Sewerage Authority (DWASA, 2013), the city experiences high concentrations of E. coli in the ground water in the downtown area while water supply is also contaminated.

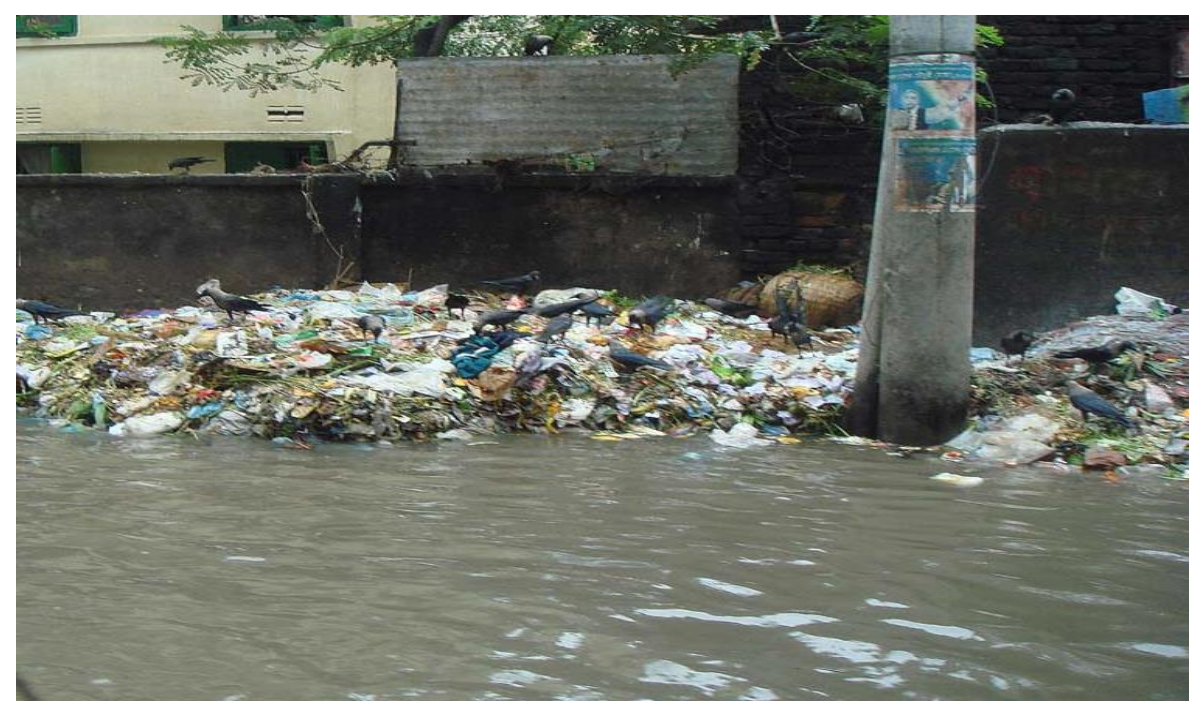

Figure 2. Waste mixing with rain water at primary collection area

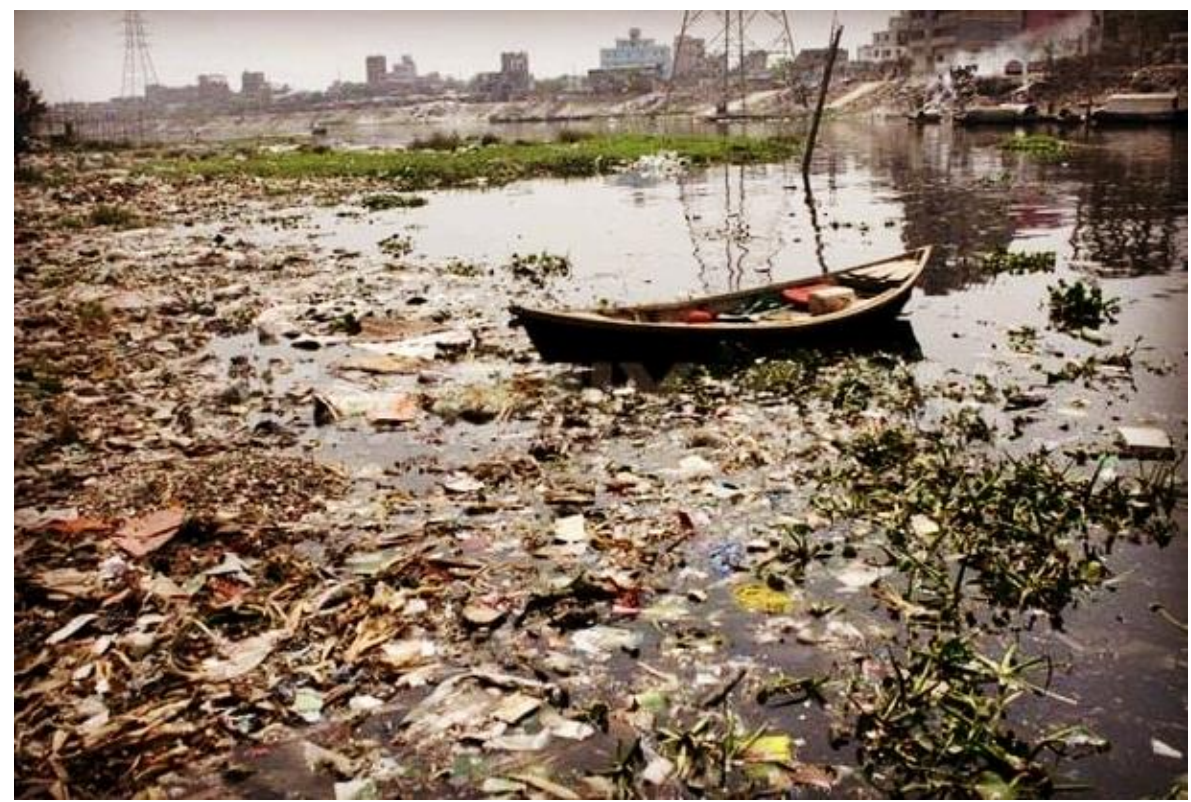

Figure 3. Bank of the river final dumping site 


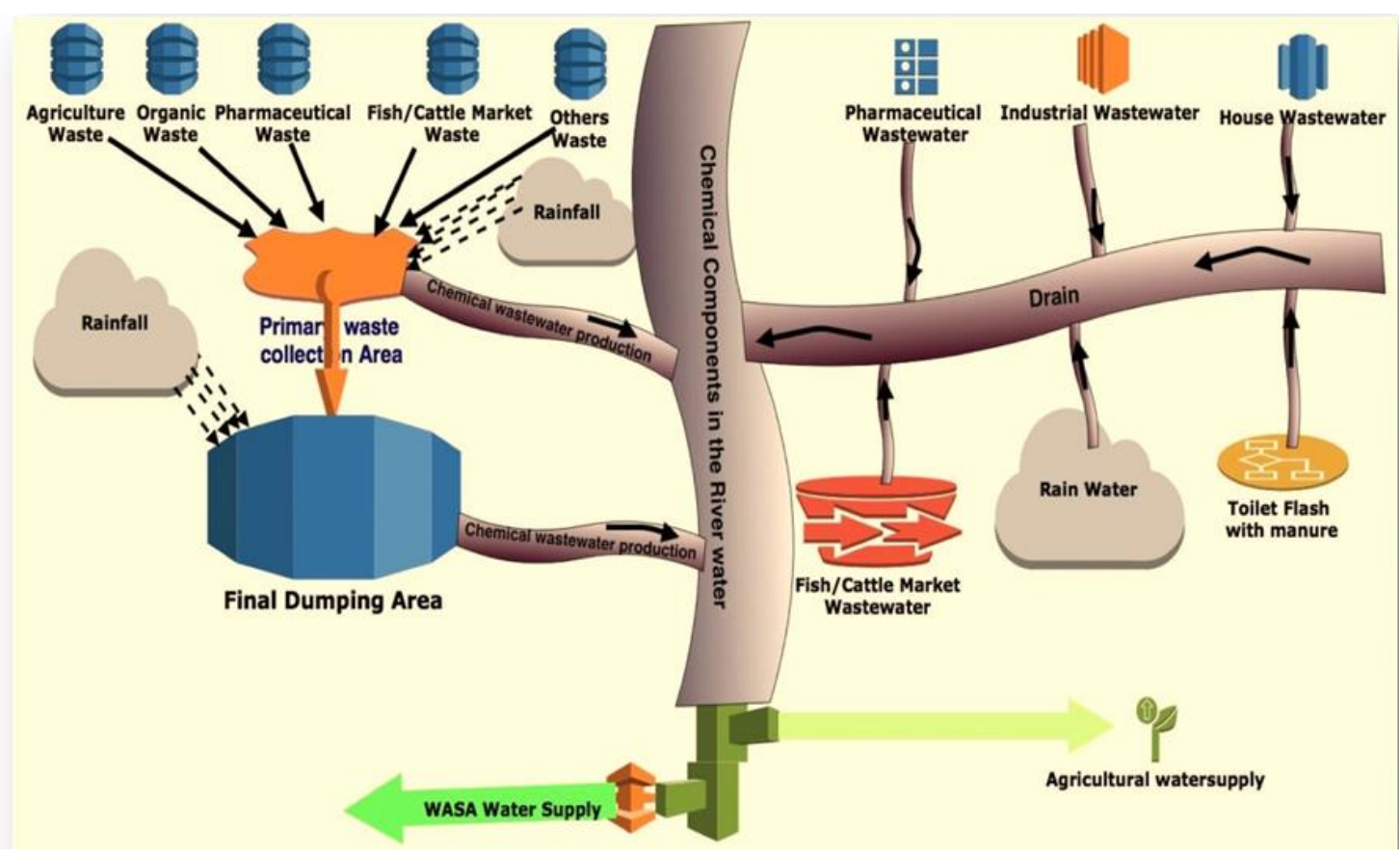

Figure 4. Waste water generation process

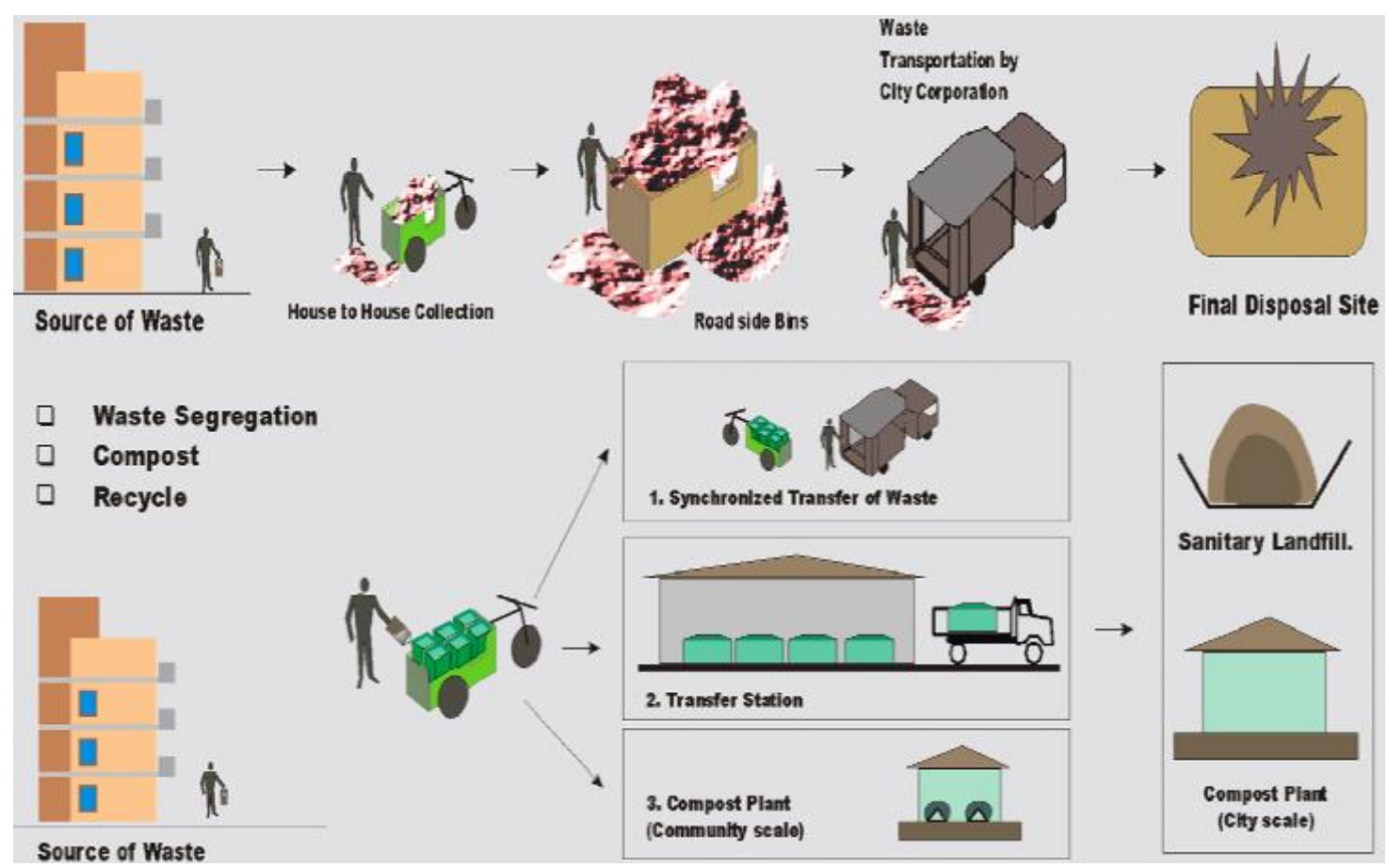

Figure 5. Traditional waste management system in Dhaka City

The fact that untreated industrial wastes are playing a critical role in the degradation of the environment, it is yet to receive international recognition. The poor in the city are highly affected by the pollution based on the current report. The city watershed has reduced by more than $30 \%$ over the past decade (Ana and Nandini, 2009). Ground water level is rapidly declining $3 \mathrm{~m} / \mathrm{yr}$ (DWASA, 2013) due to a large-scale abstraction. 
Therefore, ground water is no longer a viable option for water supply and the surface water will be the only option for water sources within the next half-century. To address the tremendous water pollution problem, specialists ought to independently collect as well as treat wastes in order to save the surface and the ground waters.

Currently there is no government agency which has carried out research concerning this on-going environmental issue. There is a great need for arsenic assessment study in the area to establish the level of waste and water pollution in the city of Dhaka (Bangladesh) as well as to assess the level of pollution and the main cause of pollution. The paper also sought to determine water quality parameter such as temperature, $\mathrm{pH}$ as well as other parameters in the water sources. In this outline, the objectives of the study were the followings: to show how wastes are converted to wastewater and mix with the water body (Figure 4); to use a high tech advance waste management system in Dhaka City and to show GHG emission load reduction in order to save the valuable water resources.

\section{Materials and methods}

\section{Study area}

The study was conducted in Dhaka City. Dhaka is situated at $23^{\circ} 42^{\prime} 58^{\prime} \mathrm{N}$ $90^{\circ} 23^{\prime} 46^{\prime \prime} \mathrm{E}$ on the eastern bank of the Buriganga River as shown in Figure 1.

\section{Water sampling and analysis}

Primary data was collected through sampling method and later on analysed independently based on the water sample origin. Water samples were collected from Buriganga River, Balu River, Turag River and in Tongi Canal around Dhaka City. Wastewater from tannery examined in the study was sourced from various sites such as Hazaribagh. Over 200 larger tanneries as well as other small ones collectively made up the largest fraction of wastewaters in the city. Grab samples collected from different drain tanneries were assessed to determine the conventional characterization of the raw tannery wastewater in the area. The recommended analyses were carried out in pair in accordance with required standard methods (Clessceri et al., 1998). More than 256 water samples from various sources were taken independently and from separate sampling points within Buriganga River, Balu River, Turag River and in Tongi Canal at Dhaka City. Of all collected water samples more than 153 were taken from $>15 \mathrm{~m}$ depth while the same number were taken from surface water. Van Dorn plastic bottles were used to gather samples. The collected water samples were stored in plastic bottles that were previously soaked in $10 \%$ nitric acid. During the study period, the researcher assessed water temperature, its $\mathrm{pH}$ as well as the concentration of dissolved solids using various instruments such as thermometer, $\mathrm{pH}$ meter respectively. The samples which were previously collected were then stored in an ice box, and transported to the lab in the same day to avoid delay.

A dilution of $1000 \mathrm{mg}$ recommended standard solutions were sourced from internationally certified lab to be used as a control in the study of the various metals. In order to prevent contamination of the samples, all the glassware and plastic containers were treated with $5 \mathrm{M} \mathrm{HNO}_{3}$ and rinsed with distilled water and completely with ultrapure water. The physicochemical levels were established using recommended techniques (Tamasi and Cini, 2004; APHA, 1998). Moreover, methyl-orange was used to assess the level of alkalinity in the sample waters. EDTA was used to measure Calcium concentration in the 
samples using of complexometric titration (Eaton et al., 1995). In respect to analysis of arsenic as well as other metals water samples were pre-concentrated different zones (Arain et al., 2007; AOAC, 1995). Saturation indices were measured using speciation-modeling to determine the equilibrium condition of the minerals in the samples (USGS, 2007).

Filtered samples of aliquot were measured by evaporation method to estimate the amount of dissolved solid in the water samples. Both Sodium (Na) and Potassium (K) were determined using flame-photometer while Calcium $(\mathrm{Ca})$ and Magnesium $(\mathrm{Mg})$ were examined by complexometric titration technique using $\mathrm{Na}_{2}$ EDTA as titrant. Other cations such as $\mathrm{Fe}^{2+}, \mathrm{Fe}^{3+}, \mathrm{Mn}^{2+}, \mathrm{Cu}^{2+}, \mathrm{Zn}^{2+}, \mathrm{B}^{3-}$, together with anions such as $\mathrm{Cl}^{-}, \mathrm{NO}_{3}{ }^{-}-\mathrm{N}, \mathrm{SO}_{4}^{2-}-\mathrm{S}$, $\mathrm{HCO}_{3}{ }^{-}$, and $\mathrm{CO}_{3}{ }^{2-}$ were examined based on recommended procedures. Qualitative test was done to detect the presence or absence of Arsenic (As). Irrigated water quality parameters viz. SAR, SSP, and $\mathrm{H}_{\mathrm{T}}$ were used to classify the suitability of waters, along with $\mathrm{pH}, \mathrm{EC}$, and TDS.

For both quality assurance and control (QA/QC), data were examined based on the recommended method (Zacheus and Martikainen, 1997). Flame atomic absorption spectrophotometer technique was used to examine sodium, iron, and potassium within given limits of $0.02 \mathrm{~g}$ LOD. Consequently, sulphate concentration together with chloride, as well as nitrate concentrations were assessed using LOD 1.2, 1.4, 1.5 and $2.7 \mathrm{~g}$, in that order. For the purpose of validation of ions, the researcher carried out ionic balance test (Lopez et al., 1999) as

$$
\text { Ion balance percent }=\left\{\frac{\sum_{\text {cations }}-\sum_{\text {anions }}}{\sum_{\text {cations }}+\sum_{\text {anions }}}\right\} \times 100
$$

On average the ion balance was around $1.18 \%$ with two outliers of around $1.8 \%$ and $-3.1 \%$ were determined, the mean of the ion balance was around $0.6 \%$ (Table 1). The parameters of SAR, SSP, and $\mathrm{H}_{\mathrm{T}}$ were measured from the analyzed data using the following formula:

$$
\begin{gathered}
S A R=\frac{\left[\mathrm{Na}^{+}\right]}{\left\{\frac{\left(\left[\mathrm{Ca}^{2+}\right]+\left[\mathrm{Mg}^{2+}\right]\right)}{2}\right\} \frac{1}{2}} \\
S S P=\frac{\text { Soluble Na concentration }\left(\mathrm{meL}^{-1}\right)}{\text { Total cation concentration }\left(\mathrm{meL}^{-1}\right)} \times 100 \\
H_{T}\left(\mathrm{mgL}^{-1}\right)=2.5 \times \mathrm{Ca}^{2+}+4.1 \times \mathrm{Mg}^{2+}
\end{gathered}
$$

Correlation coefficient analysis was done for all possible combinations within the quality parameter.

\section{Waste sample analysis}

Primary and secondary data were used for this study purpose. Secondary data was collected through various books, reports, journals and articles, such as JAICA, Ministry of Environment and Forest (MOEF), Dhaka City Corporation (DCC) reports and different waste management plants in Japan. Data collection methods included document/literature review, semi-structured interviews, checklists and observation. 
Table 1a. The mean values of physic-chemical parameters and arsenic concentration in ground water from Dhaka District, Bangladesh

\begin{tabular}{|c|c|c|c|c|c|c|c|c|c|c|c|c|c|c|c|}
\hline $\begin{array}{c}\text { Sample } \\
\text { ID }\end{array}$ & $\begin{array}{c}\mathbf{T} \\
\left({ }^{\circ} \mathbf{C}\right)\end{array}$ & pH & $\begin{array}{c}\mathrm{EC} \\
\left(\mathrm{mS} \mathrm{cm}^{-1}\right)\end{array}$ & $\begin{array}{c}\text { As } \\
(\mu \mathrm{g})\end{array}$ & $\begin{array}{l}\text { TDS } \\
\text { (mg) }\end{array}$ & $\begin{array}{l}\mathrm{Ca}^{+} \\
(\mathrm{mg})\end{array}$ & $\begin{array}{c}\mathrm{Mg2}^{+} \\
\text {(mg) }\end{array}$ & $\begin{array}{l}\mathrm{Na}^{+} \\
(\mathrm{mg})\end{array}$ & $\begin{array}{c}\mathrm{K}^{+} \\
(\mathbf{m g})\end{array}$ & $\begin{array}{c}\mathrm{HCO}_{3}{ }^{2-} \\
(\mathrm{mg})\end{array}$ & $\begin{array}{c}\mathrm{CI}^{-} \\
(\mathrm{mg})\end{array}$ & $\begin{array}{l}\mathrm{NO}_{2}^{-} \\
(\mathrm{mg})\end{array}$ & $\begin{array}{l}\mathrm{NO}_{3}^{-} \\
\text {(mg) }\end{array}$ & $\begin{array}{l}\mathrm{SO}_{4}{ }^{2-} \\
(\mathrm{mg})\end{array}$ & $\begin{array}{c}\mathrm{Fe} \\
(\mathrm{mg})\end{array}$ \\
\hline PS1 & 29.2 & 8.3 & 2.39 & 83.01 & 1148 & 219 & 49.3 & 755 & 43 & 1360 & 233 & 2.43 & 25 & 1017 & 4.01 \\
\hline PS2 & 27.3 & 7.1 & 1.7 & 14.01 & 783 & 168 & 26.3 & 653 & 9.1 & 967 & 267 & 1.39 & 12.3 & 709 & 0.26 \\
\hline PS3 & 28.5 & 8.9 & 4.15 & 108.0 & 1951 & 299 & 99.6 & 801 & 18.8 & 355 & 646 & 4.23 & 47.9 & 1519 & 4.29 \\
\hline PS4 & 26.1 & 7.1 & 3.93 & 15.31 & 1846 & 79.1 & 35.1 & 526 & 55.9 & 219 & 419 & 2.35 & 41.3 & 723 & 0.21 \\
\hline PS5 & 28.5 & 9.0 & 2.99 & 55.13 & 1396 & 102 & 63.8 & 946 & 52.7 & 537 & 718 & 1.58 & 27.5 & 1050 & 0.10 \\
\hline PS6 & 29.3 & 8.3 & 1.97 & 26.3 & 911 & 87.7 & 42.3 & 532 & 17.5 & 221 & 347 & 0.56 & 13.1 & 830 & 1.11 \\
\hline PS7 & 26.4 & 7.8 & 0.88 & 31.2 & 490 & 34.5 & 40.3 & 368 & 14.4 & 270 & 236 & 3.47 & 6.1 & 467 & 0.53 \\
\hline PS8 & 26.1 & 7.7 & 1.65 & 57.1 & 720 & 37.7 & 11.6 & 239 & 6.9 & 178 & 179 & 1.03 & 13.2 & 248 & 0.09 \\
\hline PS9 & 27,2 & 7.9 & 2.41 & 4.03 & 897 & 38.4 & 26.7 & 201 & 4.3 & 271 & 198 & 0.97 & 1.3 & 110 & 0.10 \\
\hline PS10 & 31.0 & 7.1 & 4.56 & 20.2 & 298 & 110.5 & 57.2 & 737 & 10.1 & 521 & 523 & 0.94 & 26.5 & 907 & 0.63 \\
\hline PS11 & 30.3 & 7.6 & 1.11 & 54.3 & 881 & 50 & 21.3 & 749 & 8.3 & 311 & 521 & 7.55 & 12.4 & 782 & 0.21 \\
\hline PS12 & 30.1 & 7.9 & 1.09 & 27.1 & 2227 & 89.1 & 27.9 & 561 & 17.3 & 337 & 293 & 1.22 & 12.3 & 881 & 0.60 \\
\hline PS13 & 29.4 & 8.0 & 1.01 & 55.2 & 523 & 55.5 & 18.1 & 598 & 13.1 & 287 & 278 & 0.93 & 9.7 & 411 & 0.20 \\
\hline PS14 & 28.5 & 8.1 & 2.53 & 45.1 & 497 & 38.7 & 68.3 & 297 & 17.9 & 279 & 203 & 2.53 & 12.9 & 333 & 0.20 \\
\hline PS15 & 27.4 & 7.6 & 0.49 & 43.13 & 433 & 231.2 & 23.3 & 321 & 14.0 & 513 & 513 & 2.23 & 11.9 & 1107 & 0.59 \\
\hline PS16 & 28.3 & 7.2 & 2.79 & 57.9 & 1253 & 243.5 & 25.3 & 633 & 4.0 & 304 & 464 & 2.71 & 25.6 & 1122 & 0.42 \\
\hline PS17 & 27.1 & 7.9 & 0.49 & 29.1 & 205 & 124.3 & 21.9 & 541 & 10.5 & 287 & 232 & 0.49 & 6.0 & 978 & 0.43 \\
\hline PS18 & 29.3 & 8.1 & 0.75 & 13.3 & 271 & 43.7 & 2.9 & 501 & 9.1 & 451 & 163 & 0.67 & 24.9 & 317 & 0.59 \\
\hline PS19 & 31.4 & 8 & 1.11 & 20.1 & 521 & 78.5 & 17 & 489 & 11.1 & 449 & 232 & 0.49 & 7.1 & 563 & 0.32 \\
\hline DTS1 & 32.3 & 7.9 & 1.13 & 37.2 & 347 & 71.3 & 82.5 & 339 & 8.2 & 320 & 193 & 0.99 & 6.1 & 452 & 0.14 \\
\hline DTS2 & 35.9 & 8.0 & 1.09 & 45.9 & 489 & 52.1 & 27.1 & 417 & 7.2 & 330 & 227 & 1.65 & 6.2 & 367 & 0.32 \\
\hline DTS3 & 28.1 & 7.6 & 1.13 & 66.1 & 543 & 59.5 & 21.7 & 397 & 7.9 & 220 & 143 & 0.97 & 0.9 & 723 & 0.23 \\
\hline DTS4 & 32.4 & 7.8 & 1.19 & 36.2 & 649 & 41.3 & 28.9 & 247 & 6.1 & 320 & 291 & 0.20 & 12.5 & 477 & 02.1 \\
\hline DTS5 & 25.1 & 8.1 & 1.16 & 44.9 & 621 & 61.1 & 21.1 & 241 & 7.1 & 230 & 130 & 0.30 & 0.8 & 366 & 0.50 \\
\hline DTS6 & 32.2 & 7.9 & 1.11 & 36.1 & 679 & 42.1 & 28 & 397 & 5.2 & 209 & 197 & 1.67 & 12.9 & 631 & 0.33 \\
\hline
\end{tabular}

PS: pump sample, DTS: deep tube well sample 
Table 1b. The mean values of physic-chemical parameters and arsenic concentration in surface water from Dhaka District, Bangladesh

\begin{tabular}{|c|c|c|c|c|c|c|c|c|c|c|c|c|c|c|c|}
\hline $\begin{array}{c}\text { Sample } \\
\text { ID }\end{array}$ & $\begin{array}{c}\mathbf{T} \\
\left({ }^{\circ} \mathrm{C}\right)\end{array}$ & pH & $\begin{array}{c}\mathrm{EC} \\
\left(\mathrm{mS} \mathrm{cm}^{-1}\right)\end{array}$ & $\begin{array}{c}\text { As } \\
(\mu \mathrm{g})\end{array}$ & $\begin{array}{l}\text { TDS } \\
\text { (mg) }\end{array}$ & $\begin{array}{l}\mathrm{Ca}^{+} \\
\text {(mg) }\end{array}$ & $\begin{array}{c}\mathrm{Mg2}^{+} \\
\text {(mg) }\end{array}$ & $\begin{array}{l}\mathrm{Na}^{+} \\
(\mathrm{mg})\end{array}$ & $\begin{array}{c}\mathbf{K}^{+} \\
(\mathbf{m g})\end{array}$ & $\begin{array}{c}\mathrm{HCO}_{3}{ }^{2-} \\
(\mathrm{mg})\end{array}$ & $\begin{array}{c}\mathrm{CI}^{-} \\
(\mathrm{mg})\end{array}$ & $\begin{array}{l}\mathrm{NO}_{2}^{-} \\
(\mathrm{mg})\end{array}$ & $\begin{array}{l}\mathrm{NO}_{3}^{-} \\
(\mathrm{mg})\end{array}$ & $\begin{array}{l}\mathrm{SO}_{4}{ }^{2-} \\
(\mathrm{mg})\end{array}$ & $\begin{array}{c}\mathrm{Fe} \\
(\mathrm{mg})\end{array}$ \\
\hline RS1 & 21.2 & 7.3 & 0.42 & 3.01 & 189 & 25.9 & 13.3 & 223 & 4.2 & 180 & 163 & 0.43 & 6.5 & 247 & 0.09 \\
\hline $\mathrm{RS} 2$ & 22.3 & 7.1 & 0.40 & 4.01 & 183 & 8.3 & 8.3 & 215 & 2.9 & 287 & 117 & 0.49 & 6.3 & 109 & 0.12 \\
\hline RS3 & 23.5 & 7.9 & 2.67 & 38.0 & 251 & 86.1 & 39.6 & 709 & 18.9 & 345 & 156 & 1.03 & 17.9 & 1239 & 0.39 \\
\hline MS1 & 22.1 & 7.1 & 0.43 & 5.31 & 186 & 40.1 & 15.1 & 239 & 5.9 & 249 & 179 & 0.53 & 6.3 & 196 & 0.21 \\
\hline MS2 & 21.5 & 7.0 & 0.40 & 5.13 & 256 & 13.2 & 8.1 & 183 & 6.7 & 271 & 68 & 1.58 & 5.9 & 117 & 0.10 \\
\hline MS3 & 22.3 & 8.3 & 1.84 & 16.3 & 211 & 51.7 & 21.1 & 465 & 17.9 & 231 & 272 & 0.56 & 16.1 & 613 & 0.11 \\
\hline MS4 & 22.4 & 7.0 & 0.47 & 6.31 & 190 & 16.5 & 5.5 & 243 & 7.6 & 210 & 186 & 1.13 & 6.1 & 187 & 0.13 \\
\hline MS5 & 23.1 & 7.6 & 1.69 & 50.1 & 220 & 224.7 & 36.9 & 483 & 15.9 & 278 & 359 & 0.53 & 13.1 & 988 & 0.09 \\
\hline MS6 & 25.2 & 7.1 & 0.46 & 4.03 & 197 & 12.4 & 9.5 & 211 & 5.3 & 201 & 178 & 0.97 & 6.9 & 130 & 0.10 \\
\hline MS7 & 22.5 & 7.9 & 3.62 & 5.91 & 198 & 25.5 & 12.3 & 227 & 12.1 & 191 & 173 & 0.54 & 16.5 & 207 & 0.03 \\
\hline MS8 & 23.3 & 7.2 & 0.41 & 5.01 & 211 & 6.3 & 23.6 & 271 & 35.1 & 201 & 333 & 0.55 & 6.4 & 162 & 0.11 \\
\hline MS9 & 24.1 & 7.1 & 0.49 & 4.33 & 207 & 23.1 & 17.9 & 239 & 7.3 & 197 & 223 & 0.62 & 14.3 & 181 & 0.15 \\
\hline MS10 & 22.4 & 7.0 & 0.50 & 11.02 & 230 & 17.5 & 18.1 & 213 & 15.1 & 187 & 208 & 0.73 & 4.9 & 241 & 0.13 \\
\hline MS11 & 23.5 & 7.1 & 0.53 & 7.91 & 197 & 18.7 & 11.3 & 357 & 43.1 & 479 & 243 & 2.83 & 73.9 & 263 & 0.29 \\
\hline MS12 & 23.4 & 7.5 & 0.40 & 17.13 & 233 & 11.2 & 33.3 & 401 & 15.1 & 173 & 283 & 1.53 & 11.9 & 597 & 0.11 \\
\hline MS13 & 22.3 & 7.2 & 0.49 & 6.09 & 253 & 33.5 & 3.3 & 333 & 45.7 & 164 & 244 & 1.11 & 0.8 & 352 & 0.12 \\
\hline MS14 & 22.1 & 7.1 & 3.71 & 6.11 & 215 & 22.3 & 11.9 & 241 & 14.5 & 157 & 282 & 0.59 & 0.4 & 207 & 0.03 \\
\hline MS15 & 23.3 & 7.5 & 0.55 & 5.23 & 171 & 82.1 & 2.9 & 251 & 10.1 & 151 & 243 & 3.17 & 48.9 & 217 & 0.29 \\
\hline MS16 & 22.4 & 7.8 & 3.49 & 11.21 & 121 & 22.5 & 45.5 & 539 & 7.2 & 149 & 235 & 1.29 & 13.1 & 893 & 0.02 \\
\hline MS17 & 23.3 & 7.6 & 1.44 & 11.2 & 247 & 81.3 & 25.5 & 439 & 25.1 & 123 & 196 & 1.59 & 14.1 & 622 & 0.14 \\
\hline MS18 & 24.9 & 8.0 & 3.27 & 7.99 & 169 & 32.1 & 7.1 & 327 & 14.2 & 134 & 317 & 1.50 & 3.2 & 207 & 0.12 \\
\hline MS19 & 22.1 & 8.6 & 0.91 & 8.2 & 243 & 15.5 & 10.7 & 139 & 9.1 & 118 & 63 & 0.87 & 33.1 & 243 & 0.13 \\
\hline MS20 & 23.4 & 7.5 & 0.34 & 6.09 & 149 & 42.3 & 8.9 & 297 & 6.1 & 119 & 231 & 0.50 & 12.5 & 227 & 0.11 \\
\hline
\end{tabular}


A semi-structured interview refers to a gathering in which the interviewer asks open-ended questions and allows for a discussion with the interviewee. There is no formalized process which is used while asking or answering the questions. In most cases, the interviewer asks the general questions which lead to further short questions within the discussion.

A checklist structures an individual's evaluation or observation of performance or even an artifact. They use simple criteria which can be labelled as present or absent and provide space for the observer to comment. Checklist can also be used to evaluate a database or structure out a peer observation and guide well while collecting data from a sample of the population.

The measure of combined dissolved solids in waters were determined by evaporating the filtrate of filtered samples. Sodium and Potassium levels were obtained by flame-photometer where else Calcium and Magnesium were obtained through complexometric titration using $\mathrm{Na}_{2}$ EDTA as reference sample titrant. Cations like $\mathrm{Cu}^{2+}, \mathrm{Zn}^{2+}$, and anions like $\mathrm{Cl}^{-}, \mathrm{NO}_{3}{ }^{-}-\mathrm{N}, \mathrm{SO}_{4}{ }^{2-}-\mathrm{S}, \mathrm{HCO}_{3}{ }^{-}$, and $\mathrm{CO}_{3}{ }^{2-}$ were measured through photometry. The presence or absence of Arsenic (As) metal was determined using qualitative test.

The cation levels were obtained by atomic spectrophotometry by mechanism of flame absorption for potassium, sodium and iron while for the other cations hydride generation was used in their spectrophotometry. Anion concentrations were obtained through ion chromatography (Metrohm 838) and validated then calculated using Equation 1.

Lastly, observation involved direct or indirect viewing of object whether aware or unaware if it is being observed. In observation, the researcher may choose to collect data through a set of time periods or progressive observation throughout the project.

To properly investigate on waste generation (Fig. 4) and disposal system (Fig. 2,3 \& 5), some areas were selected as sampling areas, such as Hazaribagh located at $23.734722^{\circ} \mathrm{N}, 90.369444^{\circ} \mathrm{E}$ with a total area of around $3.58 \mathrm{~km}^{2}$; Gabtoli situated at $24^{\circ} 53^{\prime} \mathrm{N} 89^{\circ} 27^{\prime} \mathrm{E}$; Uttara on the other hand is situated at $23^{\circ} 52^{\prime} \mathrm{N}$ $90^{\circ} 24.3^{\prime} \mathrm{E}$; Dholpur $\left(23.71674^{\circ} \mathrm{N} 90.4323178^{\circ} \mathrm{E}\right)$ and Mirpur located at $23.809309^{\circ} \mathrm{N} 90.360928^{\circ} \mathrm{E}$. Stratified random sampling technique was used for public opinion survey on some attributes, such as waste generation (Fig. 4), waste dumping (Fig. 2,\&3), and waste safety. The analysis was done using Urban Cobenefits Evaluation Tools and statistical tools, like Microsoft Excel used to perform calculation, visualization and analysis of data and information. It aids researchers to structure and process data through utilization of rows, columns and a combination of different formulas.

The method was to determine whether the current waste management process (Fig. 5) was being done as per legislation, the frequency in which environmental harm occurs and its significance. These measures were put in place to verify environmental damages (Fig. 3) and the optimal usage of water, energy and natural resources. In the project we have done the software simulation by classifying the wastes where combustible and non-combustible items are separated from the beginning. Step by step waste generation (Fig. 4), collection separation processes were done. Only the combustible wastes are simulated by the software. Hopefully, some medical wastes were also included in this system because in Dhaka City all 
wastes are dumped in the open pit and one dumping site. The aim was to answer the questions of this study which were: (1) how wastes convert to a wastewater stream, (2) chemical pollutants confirmation, (3) greenhouse gases production by conventional waste management procedure, and (4) a solution for saving surface water and GHG reduction

\section{Total energy in MSW}

Total energy in MSW was determined by its composition and moisture content. The MSW was reported to produce $95 \mathrm{~m}^{3}$ of methane gas per tonne with an efficiency of $80 \%$ and energy production of $12.98 \cdot 10^{5} \mathrm{KWh} /$ year (Kumar et al., 2009). The energy content of waste was measured by bomb calorimeter which entailed total combustion of the sample and then gauging the heat rise in surrounding water bath (Masters and Ela, 2013). This temperature value obtained is mainly higher in industries which manufacture products such as paper, metal and plastics. Khan et al. (1919) formulated formulas that determine temperature in food and paper industries. This formula was expressed in the equation below:

$$
\mathrm{HHV}\left(\frac{\mathrm{kJ}}{\mathrm{kg}}\right)=53.5(\mathrm{f}+3.6 \mathrm{cp})+372 \mathrm{plr}
$$

where $\mathrm{f}$ is food, $\mathrm{cp}$ is paper and cardboard, and plr is plastic. However, some amount of HHV energy is lost through vaporization of the moisture.

\section{Results}

The results for the study were as follows:

\section{Test results (water sample)}

The tests were carried out in water samples in two depths; groundwater water and surface water. The ground water samples were classified depending on the mode they are found. Pump samples (PS, $n=113$ ) were obtained at a depth range of 15.85 to $33.5 \mathrm{~m}$ and deep-tube well samples (DTS, $n=40$ ) were obtained at a depth variation up to $120 \mathrm{~m}$ depth as shown in Table la. Surface water samples were classified into two categories, namely river samples (RS, $n=33$ ) and municipal samples (MS, $n=120$ ), depending on the place the samples were obtained from. Physical and chemical analysis of all samples were done.

The $\mathrm{pH}$ and EC of all samples were measured and their range obtained. The $\mathrm{pH}$ range for PS was 7.1-9.0 while for DTS was 7.9-8.1. The EC range for groundwater samples were $0.49-4.56 \mathrm{mS} \mathrm{cm}^{-1}$ for PS and $1.09-1.10 \mathrm{mS} \mathrm{cm}^{-1}$ for DTS. Alkalinity ranged from $178-1360 \mathrm{mg}$ for both groundwater samples. The $\mathrm{pH}$ range for RS was 7.1-7.9 while that of MS was 7.0-8.6 where else the EC values ranged from $0.40-2.67 \mathrm{mS} \mathrm{cm}^{-1}$ and $0.40-3.71 \mathrm{mS} \mathrm{cm}^{-1}$, respectively. Alkalinity in both samples of surface water ranged from 118-479 mg. The composition of major ion was almost similar in both categories of surface water.

Groundwater had significant Fe concentration ranging from 0.1 to $4.01 \mathrm{mg}$ while surface water the level ranged much below the WHO recommendable range except at sampling point RS3. Arsenic concentration was more in the groundwater 
compared to surface water with ground water registering the highest level of $108 \mathrm{~g}$ compared to $50.1 \mathrm{~g}$ for surface water.

\section{Simulation results}

The simulation result is shown in Figures 6-8. Figure 6 shows almost $49 \%$ for landfill and open burning is almost $12 \%$. Figures 7 and 8 show that greenhouse gas emission is extremely high level in conventional approach.

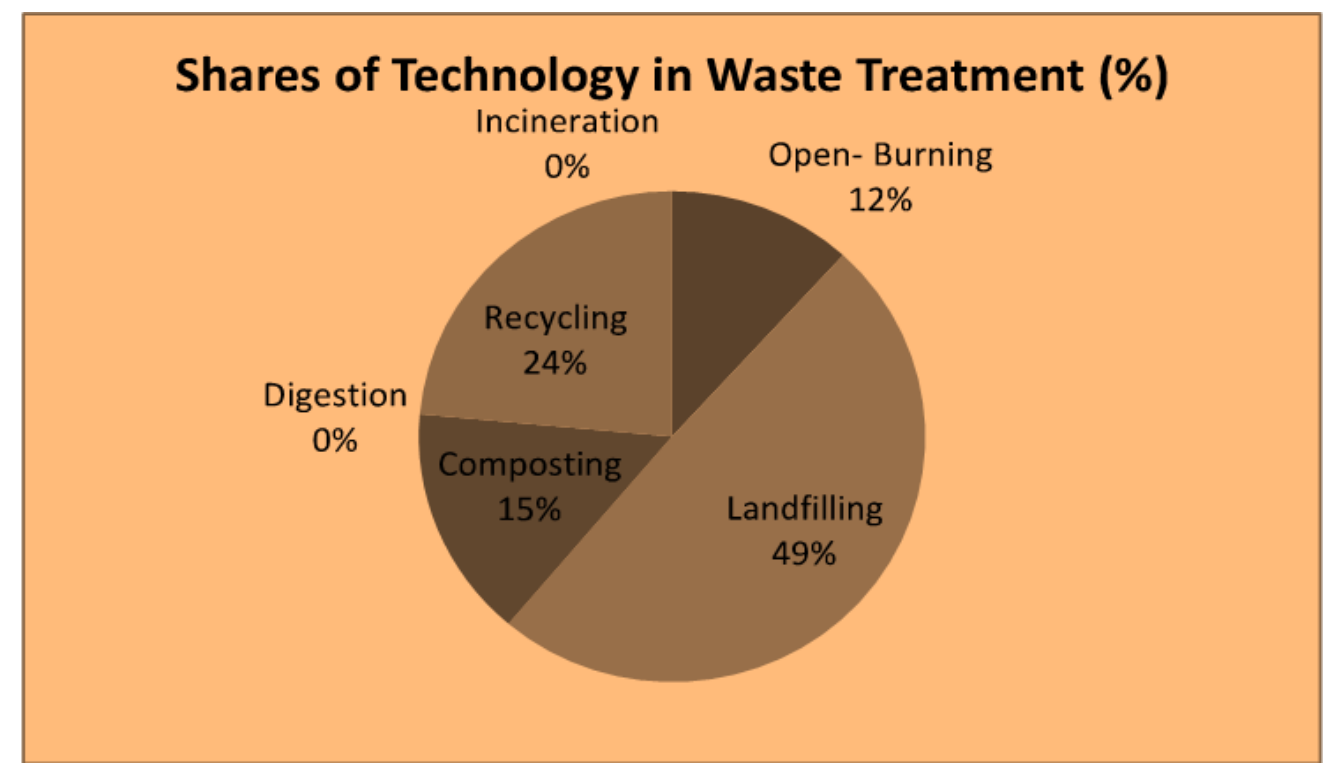

Figure 6. Current waste dumping

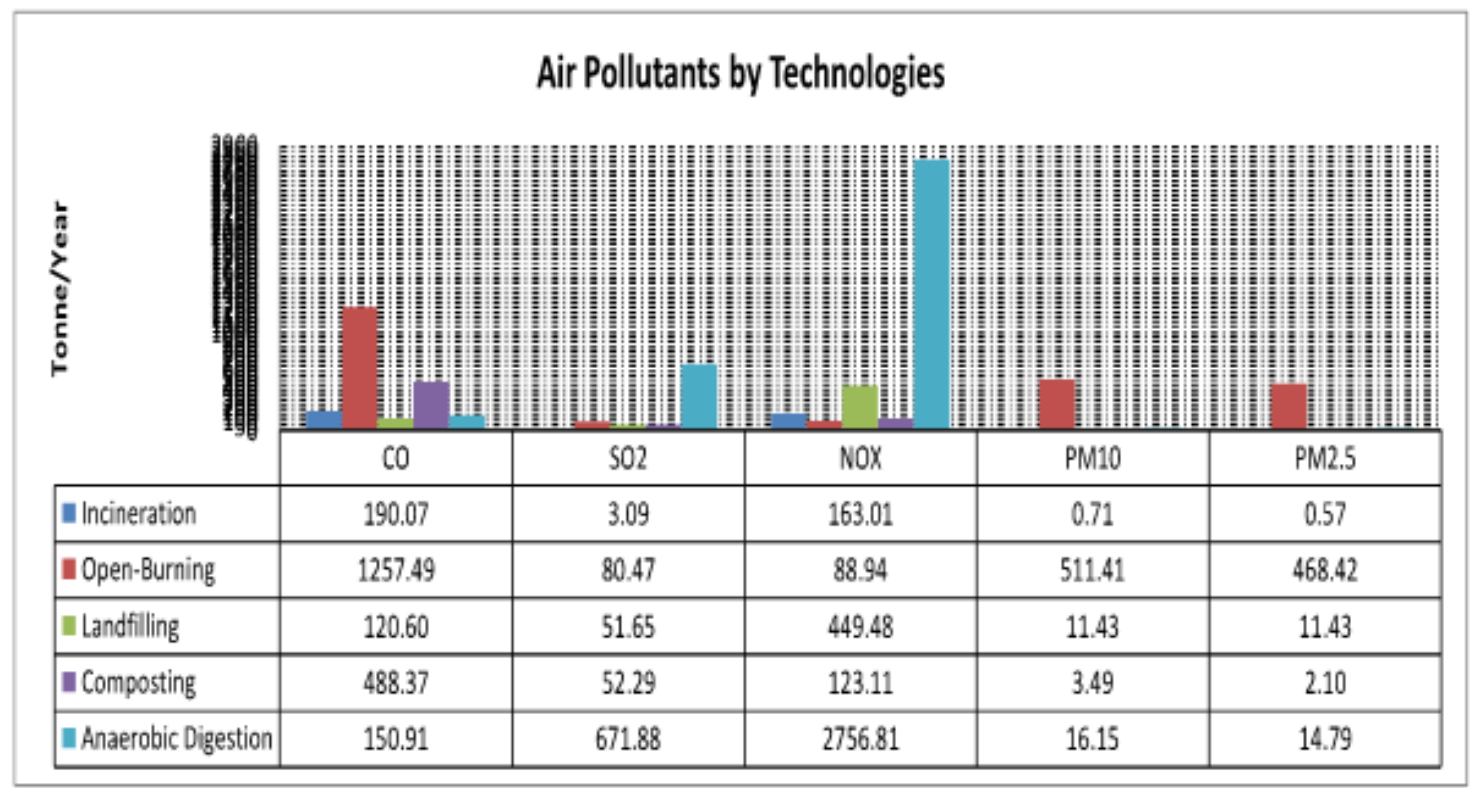

Figure 7. Current GHG emission 


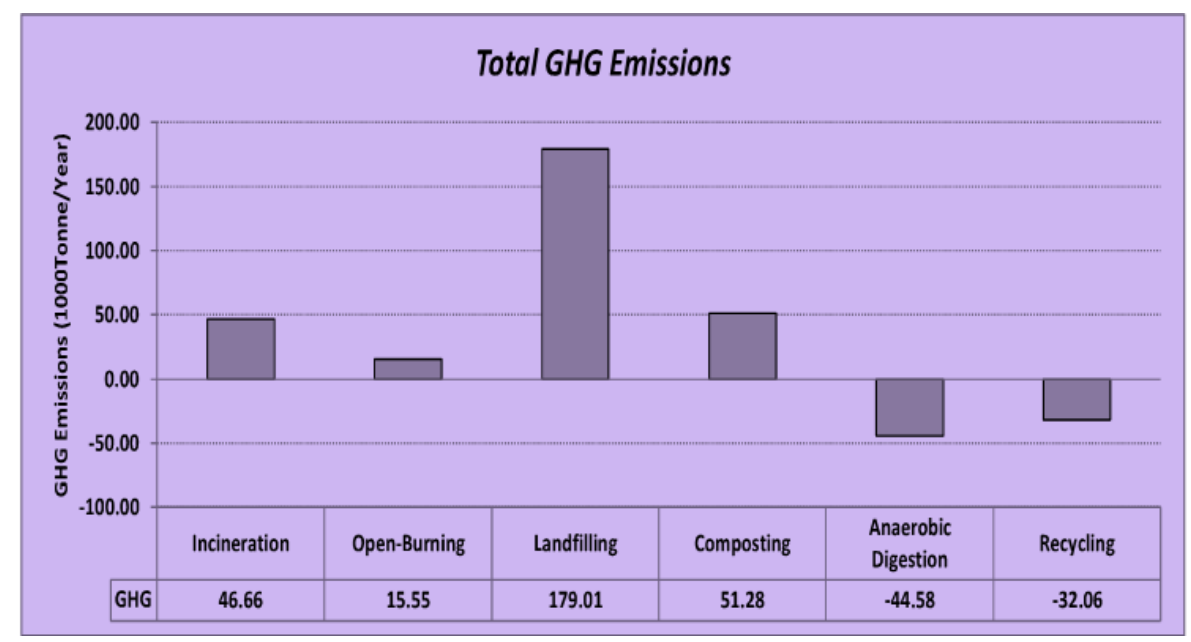

Figure 8. Current air pollution

\section{Discussion}

The $\mathrm{pH}$ of all samples was nearly above the acceptable level of World Health Organization (WHO) with high level of EC and alkalinity in samples which were obtained at deep points $(p>0.05)$. This variation in the levels of $\mathrm{pH}$ and alkalinity in groundwater samples compared to surface water samples was due to excess dissolution of organic and inorganic compounds which sediment at the ground of the water as thousands of tonnes of wastes are produced during the wet season (Fig. 2). Due to lack of proper treatment, wastes are terminated to the final dumping areas (Fig. 3) or open pits in main streets or close to the city emitting GHG gases which are dissolved in water by rainwater or seasonal water creating more anions in the surface of the water (Fig. 2), and finally the wastewaters are flowing into the rivers (Fig. 3). In the study the large concentration of cations and anions were due to more solubility of GHG gases emitted upon the burning of large quantities of waste production within the city. There was similar concentration of major ion in both municipal treated water samples and river surface water due to even distribution of ions in the water at a similar depth. There was a relative range in levels of different cations and anions. Sulphate $\left(\mathrm{SO}^{2-}\right)$ ions ranged from 109-1519 mg, chloride $\mathrm{Cl}^{-}$ions ranging from 63 to $718 \mathrm{mg}$, while Sodium ions $\left(\mathrm{Na}^{+}\right)$ranged from 139 to $946 \mathrm{mg}$. Calcium ions ranged from 6.3 to $299 \mathrm{mg}$. The levels of concentration of different cations and anions depended on the nature of waste being dumped openly in the pit and their solubility levels in water (Fig. 3).

This 3R approach in stimulant results is very good (Fig. 5). However, this approach has its limitation, it can cover only small amount of wastes per day. To tackle huge amount of wastes (12-15 thousand tons/day) that produced in Dhaka City, it is not an ideal approach. In this situation, we are proposing an advanced technology for waste management system that could cover all the wastes in Dhaka City.

\section{Proposed technology}

\section{Waste life cycle}

After reviewing the waste disposal system and 3R approach (Fig. 5) in Dhaka City, we propose a design for waste life cycle to achieve our final goal. Figure 9 shows the 
proposed life cycle for solid wastes where waste-classification is started at sources (Burnable, non-burnable, recyclable, organic particularly kitchen wastes) and each of the waste will be treated accordingly.

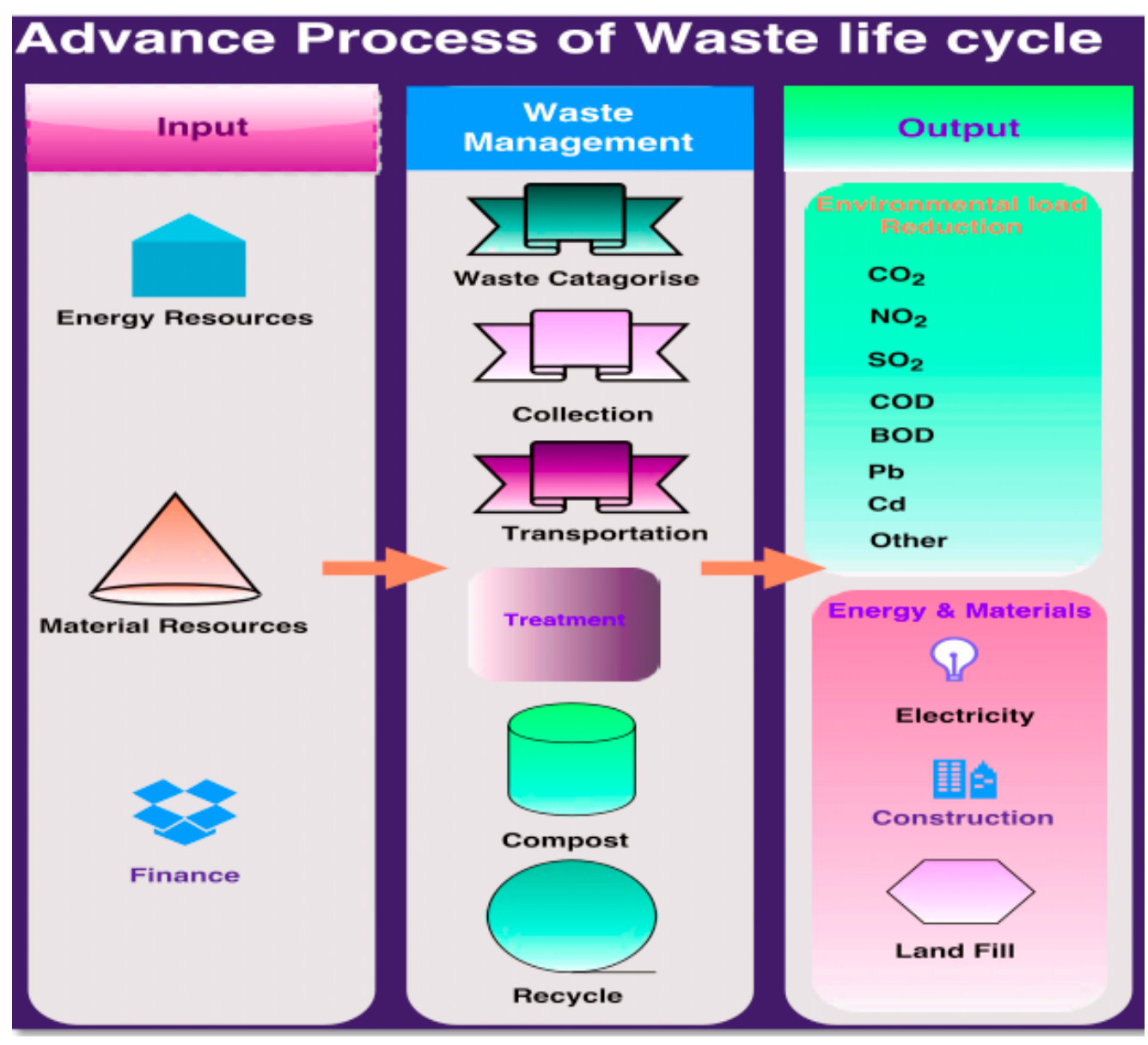

Figure 9. Proposed system

\section{Proposed treatment plant}

Figure 10 depicts incineration structure where burnable wastes are burned at 500 to $600{ }^{\circ} \mathrm{C}$ to keep valuable aluminium and un-oxidised ferrous metal that can be recovered by recycling. Non-combustible materials and sand are discharged from the bottom of the furnace through the non-combustible discharge conveyor. There are two types of separators here. If there are any ferrous metals contained in the non-combustible these are recovered with a magnetic separator, and the aluminium is recovered with an aluminium separator. The sand is stored in the sand storage tank.

Second stage is ash melting. The ash melting furnace has higher temperature because the gas is combusted while being circulated at the relatively high temperature at 1300 to $1400{ }^{\circ} \mathrm{C}$ (Kurahama Sanitary Facilities Association, Japan). This high temperature melts the ash contained in the gas, turning it into the slag, while greatly decreasing the amount of generated dioxins. The bottom of the ash-melting furnace is a discharge system for slag. Slag scraper conveyor is keeping and cooling slag by circulating cool water. This water is cooled by the water cooler and recycled for slag cooling system. Finally, slag is crushed by the slag crusher and stored in the slag storage yard. 


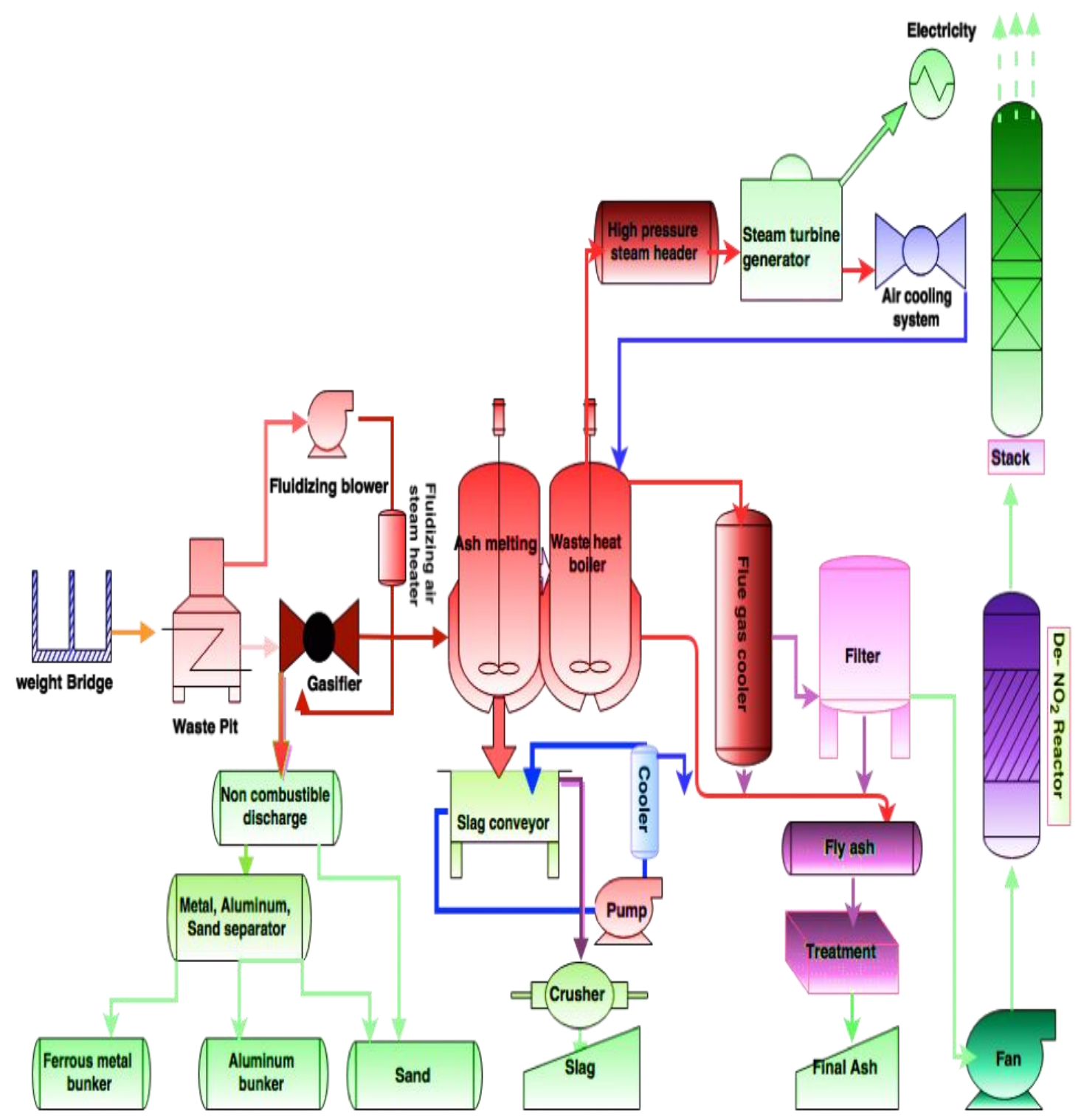

Figure 10. Advance waste treatment plant

The ash melting furnace and the waste heat boiler are directly connected to a heat boiler which has a high-pressure steam header that uses steam to generate power. The power generated is used to power the facilities and surplus sold. The steam is also used to provide hot water. The heat boiler discharges fly ash with flue gas at the bottom where the gas is taken back to the cooler while the ash is moved to a fly ash silo. This fly ash silo is also receiving ash from bag filter. Finally, fly ashes are treated by the treatment facility and sent to the hopper.

The gas is then cooled in water and filtered through filter bags made of fabrics to remove dust then reheated and passed through De- $\mathrm{NO}_{2}$ reactor which removes nitrogen oxides contained in the gas as they react with ammonia through a catalytic reaction. Finally, it will discharge to the atmosphere by the stack. If we can implement this plant, our simulation result showed that GHG emission would be the same as of Kuraham waste management plant (Kurahama Sanitary Facilities Association, Japan). Thus, we can control environmental standard. 


\section{Proposed treatment plant's simulation result}

Compared to the conventional waste treatment process, the High Tech system reduced the production of pollutants; particularly GHG is a million tonnes lower (180 to 0.03 thousand tonnes) as shown in Figure 11 and Table 2.

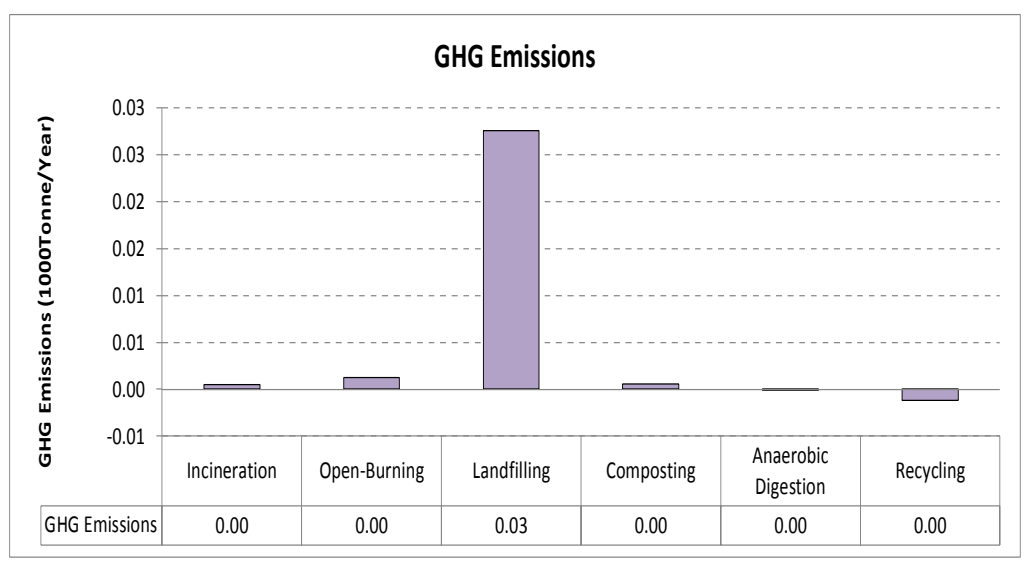

Figure 11. Advance waste treatment plant gas emission

Table 2. Ranges of analytical data of the ground and surface water sample in Dhaka District, Bangladesh

\begin{tabular}{|c|c|c|c|c|c|c|c|c|c|c|c|c|c|}
\hline \multirow{4}{*}{ Parameter } & \multirow{4}{*}{$\begin{array}{c}\text { Recommended } \\
\text { values } \\
\text { (WHO, 2004) }\end{array}$} & \multicolumn{12}{|c|}{ Water type } \\
\hline & & \multicolumn{6}{|c|}{ Ground water } & \multicolumn{6}{|c|}{ Surface water } \\
\hline & & \multicolumn{3}{|c|}{$\begin{array}{c}\text { Pump water } \\
\mathbf{n}=\mathbf{1 1 3}^{\mathrm{a}}\end{array}$} & \multicolumn{3}{|c|}{$\begin{array}{l}\text { Deep tube well water } \\
\qquad n=\mathbf{4 0}^{\mathrm{a}}\end{array}$} & \multicolumn{3}{|c|}{$\begin{array}{c}\text { River water } \\
\mathbf{n}=\mathbf{3 3}^{\mathrm{a}}\end{array}$} & \multicolumn{3}{|c|}{$\begin{array}{c}\text { MS water } \\
n=120^{\mathrm{a}}\end{array}$} \\
\hline & & Min & Max & Mean & Min & Max & Mean & Min & Max & Mean & Min & Max & Mean \\
\hline $\mathrm{T}\left({ }^{\circ} \mathrm{C}\right)$ & - & 26.1 & 31.4 & 27.1 & 25.1 & 35.9 & 31 & 21.2 & 23.5 & 22.3 & 21.5 & 25.2 & 22.9 \\
\hline $\mathrm{pH}$ & $6.5-8.5$ & 7.1 & 8.3 & 7.87 & 7.6 & 8.1 & 7.88 & 7.1 & 7.9 & 7.43 & 7 & 8.6 & 7.46 \\
\hline $\mathrm{EC}\left(\mathrm{mS} \mathrm{cm}^{-1}\right)$ & 0.40 & 0.49 & 4.56 & 2.0 & 1.09 & 1.19 & 1.14 & 0.4 & 2.67 & 1.16 & 0.34 & 3.71 & 1.27 \\
\hline TDS (mg) & 1000 & 271 & 1951 & 907.95 & 347 & 679 & 554.67 & 183 & 251 & 207.67 & 121 & 256 & 205.2 \\
\hline $\mathrm{Ca}^{+}(\mathrm{mg})$ & 100 & 37.7 & 299 & 112.13 & 42.1 & 71.3 & 54.57 & 8.3 & 86.1 & 40.1 & 6.3 & 224.7 & 39.63 \\
\hline $\mathrm{Mg}^{+}(\mathrm{mg})$ & 50 & 2.9 & 99.6 & 35.69 & 21.1 & 82.5 & 34.88 & 8.3 & 39.6 & 20.4 & 2.9 & 45.5 & 16.43 \\
\hline $\mathrm{Na}^{+}(\mathrm{mg})$ & 200 & 201 & 946 & 549.89 & 241 & 417 & 339.67 & 215 & 709 & 382.33 & 139 & 539 & 304.9 \\
\hline $\mathrm{K}^{+}(\mathrm{mg})$ & 12 & 4 & 55.9 & 17.79 & 5.2 & 8.2 & 6.95 & 2.9 & 18.9 & 8.67 & 6.1 & 45.7 & 15.96 \\
\hline $\mathrm{HCO}_{3}^{2-}(\mathrm{mg})$ & - & 178 & 1360 & 427.21 & 209 & 330 & 271.5 & 180 & 345 & 270.67 & 118 & 479 & 199.15 \\
\hline $\mathrm{CI}^{-}(\mathrm{mg})$ & 250 & 163 & 718 & 350.79 & 130 & 291 & 196.83 & 117 & 163 & 145.33 & 63 & 359 & 225.8 \\
\hline $\mathrm{NO}_{2}^{-}(\mathrm{mg})$ & 3 & 0.49 & 7.55 & 1.99 & 0.2 & 1.67 & 0.96 & 0.43 & 1.03 & 0.65 & 0.5 & 3.17 & 1.14 \\
\hline $\mathrm{NO}_{3}^{-}(\mathrm{mg})$ & 50 & 1.3 & 47.9 & 17.74 & 0.8 & 12.9 & 6.57 & 6.3 & 17.9 & 10.23 & 0.4 & 73.9 & 15.42 \\
\hline $\mathrm{SO}_{4}^{2-}(\mathrm{mg})$ & 250 & 110 & 1519 & 740.74 & 366 & 631 & 502.67 & 109 & 1239 & 531.67 & 117 & 988 & 342.5 \\
\hline As $(\mu \mathrm{g})$ & 10 & 13.3 & 108 & 39.97 & 36.1 & 66.1 & 44.4 & 3.01 & 38 & 15.00 & 4.03 & 50.1 & 10.03 \\
\hline $\mathrm{Fe}(\mathrm{mg})$ & 0.3 & 0.1 & 4.01 & 0.78 & 0.14 & 2.1 & 0.60 & 0.09 & 0.39 & 0.2 & 0.02 & 0.29 & 0.13 \\
\hline
\end{tabular}

\section{Conclusion}

The research concluded that the level of arsenic in different samples was higher than the acceptable level expected by WHO. The higher levels were mainly found in the ground water compared to the surface water were mainly due to waste dumping factors including the nature of waste, solubility that influence $\mathrm{pH}$ level, and concentration of different cations and anions. This High Tech waste treatment plant can potentially 
reduce totally 2.4 million tons GHG per year. The plant can also produce $256.125 \mathrm{MW}$ electricity daily. Thus, the system is self-sustainable and environmental friendly. It will reduce polluted wastewater effluents from flowing into the water bodies and GHG emission in the environment significantly. Further research is required to identify how electricity can be generated. Moreover, the study was conducted in a developing country. To enable generalization of the findings, the study suggests a similar research to be conducted concerning under-developed and developed nations.

\section{REFERENCES}

[1] Ana, M., Nandini, D. (2009): Industrial water pollution in Dhaka, Bangladesh: strategies and incentives for pollution control in small and medium enterprises. - The International Journal of Interdisciplinary Social Sciences 3(11): 97-108.

[2] Anawar, H. M., Akai, J., Komaki, K., Terao, H., Yoshioka, T., Ishizuka, T., Safiullah, S., Kato, K. (2003): Geochemical occurrence of arsenic in groundwater of Bangladesh: sources and mobilization processes. - J. Geochem. Explor. 77: 109-131.

[3] Antoniadis, V., Golia, E. E., Shaheen, S. M., Rinklebe, J. (2017): Bioavailability and health risk assessment of potentially toxic elements in Thriasio Plain, near Athens, Greece. - Environmental Geochemistry and Health 39(2): 319-330.

[4] AOAC, Association of Official Analytical Chemists (1995): Official Methods of Analysis. 16th Ed. - AOAC International, Gaithersburg, MD (March 1998 revision).

[5] APHA (American Public Health Association) (1998): Standard Methods for the Examination of Water and Wastewater. 20th Ed. - APHA, American Water Works Association, and Water Pollution Control Federation, Washington, DC.

[6] Arain, M. B., Kazi, T. G., Jamali, M. K., Jalbani, N., Afridi, H. I., Shah, A. (2007): Total dissolved and bioavailable elements in water and sediment samples and their accumulation in Oreochromis mossambicus of polluted Manchar Lake. - Chemosphere 70: $1845-1856$.

[7] Bettoschi, A., Marrucci, A., Marras, B., Atzori, M., Schintu, M. (2018): Arsenic speciation in marine sediments: a comparison between two sequential extraction procedures. - Soil and Sediment Contamination: An International Journal 27(8): 723-735.

[8] Chandan, C., Mazaharul, H. M., Sobur, A., Taslima, T., Miah, R. M. (2013): Analysis of the causes and impacts of water pollution of Buriganga River: a critical study. International Journal of Scientific \& Technology Research 2: 245-252.

[9] Chappell, W. R., Abernathy, C. O., Calderon, R. L. (eds.) (2001): Arsenic Exposure and Health Effects. Vol. 24. - Elsevier, New York, pp. 27-52.

[10] Chatterji, M., Arlosoroff, S., Guha, G. (2017): Conflict Management of Water Resources. - Routledge, London.

[11] Clesceri, L. S., Greenberg, A. E., Eaton, A. D. (eds.) (1998): Standard Methods for the Examination of Water and Wastewater. 20th Ed. - American Public Health Association, Washington, DC, USA.

[12] Cordon, G., Iriel, A., Cirelli, A. F., Lagorio, M. G. (2018): Arsenic effects on some photophysical parameters of Cichorium intybus under different radiation and water irrigation regimes. - Chemosphere 204: 398-404.

[13] Cui, J. L., Zhao, Y. P., Li, J. S., Beiyuan, J. Z., Tsang, D. C., Poon, C. S., ... Li, X. D. (2018): Speciation, mobilization, and bioaccessibility of arsenic in geogenic soil profile from Hong Kong. - Environmental Pollution 232: 375-384.

[14] Eaton, D. A., Clesceri, L. S. (1995): Greenberg, Standard Methods. 19th Ed. for the Examination of Water and Wastewater. - American Public Health Association, Washington, DC. 
[15] Elci, L., Divrikli, U., Soylak, M. (2008): Inorganic arsenic speciation in various waters amples with GF-AAS using coprecipitation. - Int. J. Environ. Anal. Chem. 88: 711-723.

[16] Huang, X., Betha, R., Tan, L. Y., Balasubramanian, R. (2016): Risk assessment of bioaccessible trace elements in smoke haze aerosols versus urban aerosols using simulated lung fluids. - Atmospheric Environment 125: 505-511.

[17] Ijumulana, J., Mtalo, F., Bhattacharya, P., Bundschuh, J. (2016): Arsenic Occurrence in Groundwater Sources of Lake Victoria Basin in Tanzania. - In: Arsenic Research and Global Sustainability: Proceedings of the Sixth International Congress on Arsenic in the Environment (As2016), June 19-23, 2016, Stockholm, Sweden. CRC Press, Boca Raton, FL.

[18] Khuhawar, M. Y., Ursani, H., Khuahwar, T. M. J., Lanjwani, M. F., Mahessar, A. A. (2019): Assessment of Water Quality of Groundwater of Thar Desert, Sindh. Pakistan. J Hydrogeol Hydrol Eng 7(2): 2.

[19] Kumar, A., Kumar, R., Rahman, M. S., Iqubal, M. A., Anand, G., Niraj, P. K., Ali, M. (2015): Phytoremedial effect of Withania somnifera against arsenic-induced testicular toxicity in Charles Foster rats. - Avicenna Journal of Phytomedicine 5(4): 355.

[20] Kumar, S., Bhattacharyya, J., Vaidya, A., Chakrabati, T., Devotta, S. and Akolkar, A.(2009): Assesment of the status of municipal solid waste management in metro cities, state capitals, class I cities, and class II towns in India: An insight. - Waste Management 29: 883-395.

[21] Lopez, P. L., Auque, L. F., Garces, I., Chong, W. (1999): Geochemical characteristics and patterns of evolution of Salmueras superficiales del Salar de Llamara, Chile Brines surface of Salar Llamara, Chile. - Geol. Mag. Chile 26: 89-108.

[22] Man-Hong H., Yong-mei, L., Guo-wei, G. (2010): Chemical composition of organic matter in domestic wastewater. - Desalination 262: 36-42.

[23] Mehrotra, A., Mishra, A., Tripathi, R. M., Shukla, N. (2016): Mapping of arsenic contamination severity in Bahraich district of Ghagra basin, Uttar Pradesh, India. Geomatics, Natural Hazards and Risk 7(1): 101-112.

[24] Milton, A. H., Hasan, Z., Shahidullah, S. M., Sharmin, S., Jakariya, M. D., Rahman, M., Keithdear, and Smith, W. (2004): Association between nutritional status and arsenicosis due to chronic arsenic exposure in Bangladesh. - Int. J. Environ. Health Res. 14: 99-108.

[25] Mohammadi, S., Kargari, A., Sanaeepur, H., Abbassian, K., Najafi, A., Mofarrah, E. (2015): Phenol removal from industrial wastewaters: a short review. - Desalination and Water Treatment 53(8): 2215-2234.

[26] Ouyang, Y., Peng, Y., Li, J., Holmgren, A., Lu, J. (2018): Modulation of thiol-dependent redox system by metal ions via thioredoxin and glutaredoxin systems. - Metallomics 10(2): 218-228.

[27] Pariatamby, A., Tanaka, M. (eds.) (2014): Municipal Solid Waste Management in Asia and Pacific Island: Challenges and Strategic Solutions. - Springer, Singapore.

[28] Rehman, S., Hussain, Z., Zafar, S., Ullah, H., Badshah, S., Ahmad, S. S., Saleem, J. (2018): Assessment of ground water quality of Dera Ismail Khan, Pakistan, using multivariate statistical approach. - Science 37(4): 173-183.

[29] Shaikha, B. A., Zubayed, B. R. (2013): Generation and quality analysis of greywater at Dhaka City. - Environmental Research, Engineering and Management 2(64): 29-41.

[30] Song, L., Mao, K., Zhou, X., Hu, J. (2016): A novel biosensor based on Au@ Ag coreshell nanoparticles for SERS detection of arsenic (III). - Talanta 146: 285-290.

[31] Tamasi, G., Cini, R. (2004): Heavy metals in drinking waters from Mount Amiata (Tuscany, Italy) Possible risks from arsenic for public health in the Province of Siena. - Sci. Total. Environ. 327: 41-51.

[32] Tripathee, L., Kang, S., Rupakheti, D., Zhang, Q., Bajracharya, R. M., Sharma, C. M., ... Sillanpää, M. (2016): Spatial distribution, sources and risk assessment of potentially toxic trace elements and rare earth elements in soils of the Langtang Himalaya, Nepal. Environmental Earth Sciences 75(19): 1332. 
[33] U.S. Environmental Protection Agency (1984): Characterization of Hazardous Waste Sites. A Methods Manual: Volume II. Available Sampling Methods. Second Ed. EPA/600/4-84-076, EPA, Washington, DC.

[34] WHO (1996): Guidelines for Drinking Water Quality, Vol. 2. Health Criteria and Other Supporting Information. 2nd Ed. - World Health Organization, Geneva.

[35] Zacheus, O. M., Martikainen, P. J. (1997): Physicochemical quality of drinking and hot waters in Finnish buildings originated from groundwater or surface water plants. - Sci. Total. Environ. 204: 1-10. 